\title{
Penerapan Strategi E-business Untuk Meningkatkan Keunggulan Kompetitif dari Usaha Mikro Kecil Menengah di Indonesia (Studi kasus Trooper Electronic Yogyakarta)
}

\author{
Yonathan Dri Handarkho ${ }^{1}$, Timothy Ryan Suryanto ${ }^{2}$, Findra Kartika Sari Dewi ${ }^{3}$, Eddy Julianto ${ }^{4}$ \\ ${ }^{1,2,3,4}$ Program Studi Teknik Informatika, Fakultas Teknologi Industri, Universitas Atma Jaya Yogyakarta \\ Jl. Babarsari 43, Yogyakarta 55281 \\ E-mail: ${ }^{1}$ yonathan_dh@staff.uajy.ac.id, ${ }^{2}$ timothy.ryan.suryanto@gmail.com, ${ }^{3}$ findra@staff.uajy.ac.id, \\ eddiedb@staff.uajy.ac.id
}

Masuk: 19 Juli 2017; Direvisi: 13 Agustus 2017; Diterima: 13 Agustus 2017

\begin{abstract}
Today, many micro small medium enterprises (MSME) utilize the internet technology to enhance their competitive advantage. One of the popular strategies is the use of e-business to enhance business process performance of the organization. However, to implement e-business strategy, an organization needs to have a model that can help align e-business strategy with organization strategy. That is why in this research, the authors try to apply and implement e-business strategy in MSME Trooper Electronic Yogyakarta by using e-business evaluation model proposed by Raisinghani et al. (2007). In this research, an e-commerce website for Trooper Electronic Yogyakarta will be developed and the use of social media will be maximized.
\end{abstract}

Keyword: e-business, model, e-commerce, social media, MSME

\begin{abstract}
Abstrak. Penerapan Strategi E-business Untuk Meningkatkan Keunggulan Kompetitif dari Usaha Mikro Kecil Menengah di Indonesia (Studi Kasus Trooper Electronic Yogyakarta). Berkembangnya teknologi internet membuat banyak pelaku usaha termasuk UMKM mulai memanfaatkan teknologi tersebut untuk meningkatkan keunggulan kompetitifnya. Strategi pemanfaatan teknologi internet untuk meningkatkan performa proses bisnis dari sebuah unit usaha disebut sebagai E-business. Hanya saja untuk menerapkan strategi e-business tersebut, unit usaha seperti UMKM memerlukan sebuah model atau kerangka kerja yang dapat membantu mereka memastikan bahwa strategi yang mereka terapkan sesuai dengan kondisi dan proses bisnis dari UMKM tersebut. Terkait dengan hal tersebut, pada penelitian ini, penulis mencoba menerapkan dan mengimplementasikan strategi e-busines pada UMKM Trooper Electronic Yogyakarta dengan mengadopsi model strategi e-busines yang diusulkan oleh Raisinghani dkk. (2007). Penerapan strategi e-business pada penelitian ini diwujudkan dalam bentuk pembangunan web e-commerce dan pemanfaatan media sosial untuk mendukung proses bisnis dari UMKM Trooper Electronic Yogyakarta.
\end{abstract}

Kata Kunci: e-business, model, e-commerce, media sosial, UMKM

\section{Pendahuluan}

Saat ini, teknologi internet telah berkembang menjadi sebuah strategi baru yang dapat dimanfaatkan oleh pelaku usaha untuk meningkatkan dan mengembangkan bisnis yang mereka kelola. E-business adalah salah satu contoh dari strategi berbasis teknologi internet yang dapat membantu pelaku usaha untuk berkomunikasi dan mendistribusikan barang dan jasanya kepada konsumen. Ebusiness sendiri bisa didefiniskan sebagai penggunaan teknologi internet untuk meningkatkan performa dari proses bisnis yang meliputi penjualan dan pembelian produk dan jasa melalui situs web yang melibatkan stakeholder seperti konsumen, pemilik usaha, vendor dan pemasok (Raisinghani, dkk., 2007).

Saat ini, pemanfaatan strategi $e$-business tidak hanya didominasi oleh unit usaha berskala besar saja. Banyak pelaku usaha mikro kecil menengah (UMKM) yang mulai memanfaatkan strategi $e$ business sebagai bagian dari strategi yang diharapkan mampu meningkatkan performa bisnis mereka. 
Hal tersebut dikarenakan teknologi informasi merupakan salah satu instrumen yang dirasa efektif mampu meningkatkan keunggulan kompetitif sebuah unit usaha ditengah persaingan yang begitu ketat (Stale \& Majors, 2010). Banyak pelaku UMKM di negara berkembang di Asia seperti di Malaysia (Yee-Loong Chong, dkk., 2014) dan di Indonesia (Rahayu \& Day, 2015) yang mulai melibatkan strategi $e$-business untuk menunjang proses bisnis mereka. Salah satu strategi e-business yang banyak digunakan oleh pelaku UMKM di kedua negara tersebut adalah e-commerce. Teknologi e-commerce menawarkan kemudahaan dalam proses pendistribusian barang, jasa dan informasi ke konsumen dengan cepat dan efektif (Lu \& Liu, 2015). Melalui pemanfaatan e-commerce, banyak UMKM yang bisa memperoleh keuntungan strategis seperti terintegrasinya proses bisnis dari sisi internal dan eksternal, bertumbuhnya jangkauan pasar yang semakin luas, dan meningkatnya relasi dan komunikasi dengan konsumen (Poorangi, dkk., 2013). Diharapkan melalui penerapan strategi e-business, para pelaku UMKM akan mampu meningkatkan keunggulan dan daya saing mereka di dunia usaha (Pramudiya, dkk., 2015).

Salah satu UMKM di Indonesia yang mulai melibatkan teknologi internet untuk meningkatkan keunggulan kompetitifnya adalah Trooper Electronic Yogyakarta. UMKM ini berdiri sejak tahun 2008 dan bergerak pada bidang usaha pembuatan amplifier untuk gitar, pedal efek (stompbox) untuk gitar dan perangkat sound system yang semuanya dibuat secara hand made di workshop "Trooper Elektronik" yang terletak di daerah Widomartani Sleman. UMKM tersebut melayani konsumen yang berasal dari kalangan musisi baik dari level amatir sampai profesional tidak hanya dari Yogyakarta saja, tetapi juga dari berbagai daerah di Indonesia. Selama ini saalah satu strategi yang sudah digunakan Trooper Electronic untuk meningkatkan keunggulan kompetitifnya adalah dengan memanfaatkan media sosial seperti Facebook, Instagram serta WhatsApp untuk menjalin komunikasi dengan konsumen serta mempromosikan produk mereka secara manual. Melihat peluang besar yang ditawarkan melalui strategi e-business terutama untuk menjangkau pasar yang lebih besar, Trooper Elektronik juga memiliki rencana untuk mengembangkan strategi bisnisnya dengan memanfaatkan teknologi internet.

Hanya saja untuk menerapkan strategi e-business, para pelaku usaha perlu untuk memastikan bahwa strategi yang mereka pilih mendukung dan sesuai dengan strategi bisnis yang telah mereka miliki sebelumnya (Sudirman, dkk., 2015). Oleh sebab itu para pelaku UMKM memerlukan sebuah model atau kerangka kerja yang bisa menuntun mereka untuk memilih strategi $e$-business yang tepat dan sesuai. Hal tersebut penting untuk diperhatikan, karena stretegi e-business yang tepat mampu mentransformasikan proses bisnis dari sebuah organisasi, yang selanjutnya dapat meningkatkan keunggulan kompetitif dari organisasi tersebut (Raisinghani, 2001).

Terkait dengan strategi e-business, terdapat beberapa model yang dapat diajukan untuk mengevaluasi dan menuntun penyusunan strategy e-business yang dibangun berdasarkan metode evaluasi Balanced Scorecard (BSC). Metode BSC pertama kali diajukan oleh Kaplan \& Norton (1992) dan mengalami berbagai modifikasi sampai saat ini. Awalnya metode ini digunakan untuk mengevaluasi performa dari organisasi dari empat perspektif yaitu finansial, konsumen, proses bisnis internal, dan inovasi \&pembelajaran. Seiring berjalannya waktu, metode BSC banyak diadopsi untuk mengevaluasi investasi organisasi salah satunya investasi dalam bidang teknologi informasi (Martinsons, dkk., 1999). Terkait dengan proses evaluasi terhadap strategi $e$-business, terdapat beberapa model yang dikembangkan dengan memodifikasi empat perspektif dari metode BSC (Hasan \& Tibbits, 2000) (Raisinghani, 2001) (Van Grembergen \& Amelinck, 2002) (Plant, dkk., 2003) dan bahkan mengkombinasikannya dengan metode dan model lain (Raisinghani, dkk., 2007). Melalui model tersebut, diharapkan organisasi dapat memperoleh tuntunan dan pengukuran yang dapat digunakan untuk memastikan strategi e-business yang mereka pilih bisa diterapkan dan sesuai dengan kondisi mereka.

Pada makalah ini, penulis mencoba menerapkan dan mengimplementasikan strategi e-business pada UMKM Trooper Electronic Yogyakarta dengan mengadopsi model strategi e-busines yang diusulkan oleh Raisinghani, dkk. (2007). Penerapan strategi e-business salah satunya diwujudkan dengan mengembangkan sebuah web e-commerce yang dibangun berdasarkan tuntunan dari model yang diajukan oleh Raisinghani, dkk. (2007). Bentuk penerapan lain dari strategi e-business adalah dengan memaksimalkan penggunaan sosial media, mengingat Trooper Electronic telah menggunakan sosial media sebelumnya untuk membantu bisnis mereka. Model yang diusulkan oleh Raisinghani, dkk. 
(2007) pada dasarnya dibagi menjadi dua bagian yaitu model strategi level bisnis yang bisa digunakan sebagai tuntunan untuk menyusun strategi bisnis dari UMKM dan bagian yang kedua adalah model yang menyediakan pengukuran untuk menyusun strategi e-business. Raisinghani, dkk. (2007) mengkombinasikan kedua model tersebut menggunakan model Analitic Network Process (ANP) untuk mendapatkan strategi e-business yang sesuai dan bersinergi dengan strategi bisnis dari sebuah organisasi. Pada penelitian ini, penulis hanya akan mengadopsi model strategi $e$-business yang diajukan oleh Raisinghani, dkk. (2007) untuk menerapkan strategi e-business yang sesuai dengan kebutuhan dan kondisi dari Trooper Electronic Yogyakarta yang diharapkan dapat meningkatkan keunggulan kompetitif dari UMKM tersebut.

\section{Landasan Teori}

\subsection{Model Evaluasi Strategi $E$-business}

Terdapat beberapa model dari penelitian sebelumnya yang telah diajukan untuk mengevaluasi dan menyusun strategi $e$-business yang sesuai dengan kebutuhan dari sebuah UMKM. Masing masing model tersebut menyediakan tuntunan dan pengukuran yang dapat digunakan untuk menyusun strategi $e$-business yang sesuai dengan kebutuhan organisasi. Salah satunya adalah model yang diajukan oleh Van Grembergen \& Amelinck (2002). Model dari Van Grembergen \& Amelinck (2002) mengadopsi metode BSC dengan menilai strategi dari e-business berdasarkan pengukuran yang diperoleh dari empat buah perspektif yaitu: a) seberapa besar strategi e-business memberikan kontribusi bisnis dari sebuah organisasi; b) apakah strategi e-business tersebut berorientasi ke masa yang akan datang; c) apakah strategi e-business berorientasi kepada konsumen; dan d) apakah strategi e-business memberikan keunggulan dalam hal operasional. Hampir serupa dengan model di atas, Plant, dkk. (2003) juga mengusulkan model untuk mengevaluasi strategi e-business berdasarkan perspektif dari metode BSC. Yang membedakan adalah Plant, dkk. (2003) menambahkan empat buah sub perspektif kedalam perspektif konsumen. Menurut Plant, dkk. (2003), organisasi yang hendak menerapkan strategi $e$ business sebagai bagian dari strategi bisnis organisasi harus memberikan perhatian kepada empat sub perspektif tersebut yaitu merek, layanan, pasar dan teknologi.

Sedikit berbeda dengan kedua model di atas yang mengembangkan model evaluasi strategi $e$ business dengan melakukan modifikasi dari metode evaluasi BSC, Raisinghani, dkk. (2007) mengajukan model evaluasi strategi e-business dengan mengkombinasikan dua buah model evaluasi yaitu model evaluasi strategi bisnis yang diadopsi dari metode BSC (Raisinghani, 2001) dan model evaluasi strategi e-business yang diadopsi dari model yang diajukan oleh Angehrn (1997) bernama "the four domains of internet expansion model" atau disingkat model ICDT (Information, Communication, Distributon, and Transaction). Kedua model evaluasi tersebut dikombinasikan dengan menggunakan pendekatan Analytic Network Process (ANP) untuk mendapatkan strategi e-business yang paling optimal. Gambar 1 menunjukan gambaran umum dari model ANP yang diadopsi dari Raisinghani, dkk. (2007).

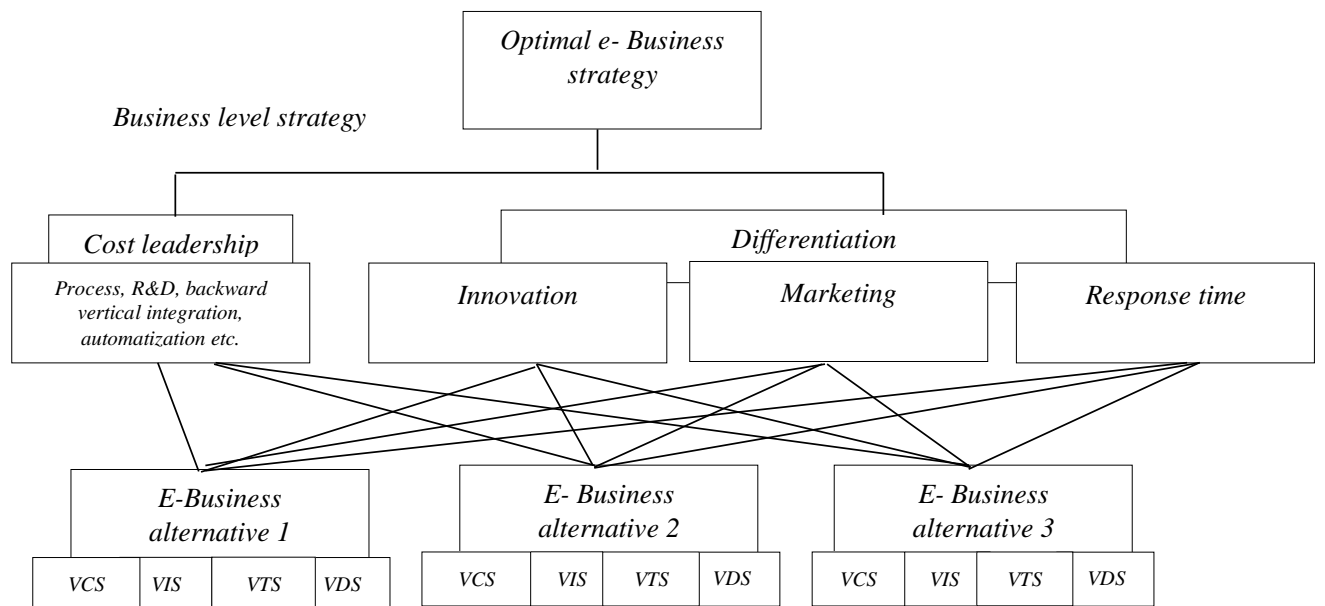

Gambar 1. Model ANP untuk menentukan strategi $e$-business yang paling optimal (diadopsi dari Raisinghani, dkk. 2007) 
Seperti telah disebutkan di atas, strategi e-business dievaluasi menggunakan model ICDT yang diadopsi dari Angehrn (1997). Model tersebut menyediakan elemen elemen yang bisa dipergunakan untuk menjelaskan bagaimana strategi e-business bisa membantu meningkatkan keunggulan kompetitif dari sebuah organisasi (Raisinghani, 2001). Model ICDT tersusun dari empat buat elemen yaitu Virtual Communication Space (VCS), Virtual Infromation Space (VIS), Virtual Transaction Space (VTS), dan Virtual Distribution Space (VDS). Gambar 2 menunjukkan detil dari model ICDT.

\subsection{Model ICDT}

Seperti telah disebutkan sebelumnya, Model yang dipergunakan oleh Raisinghani et al. (2007) untuk mengevaluasi dan mengukur strategi e-business dari sebuah organisasi diadopsi dari model ICDT yang diusulkan oleh Angehrn (1997). Model tersebut terdiri dari empat buah dimensi yaitu VIS, VCS, VDS, dan VDT (Gambar 2). Dimensi VIS (Information) berhubungan dengan penggunaan teknologi internet untuk menyebarkan dan menampilkan informasi seperti jasa, produk, serta profil dari organisasi. VIS juga dikaitkan dengan aktifitas periklanan dan pemasaran menggunakan teknologi internet. Dimensi kedua, VCS (Communication), berhubungan dengan penggunaan teknologi internet untuk menjalin komunikasi dan kolaborasi antara agen ekonomi di internet yang bisa diwujudkan dalam bentuk B2B atau B2C. Dimensi ketiga, VDS (Distribution) berhubungan dengan penggunaan teknologi internet untuk mendistribusikan produk atau jasa yang bisa dikategorikan menjadi: a) produk digital seperti e-books, musik digital, perangkat lunak, video dan lain sebagainya; b) layanan digital seperti konsultasi dan pelatihan online, layanan berlangganan (subcription) dan lainnya; c) layanan tambahan yang berhubungan dengan produk atau layanan tradisional seperti informasi mengenai produk atau jasa tertentu, layanan pelanggan (customer service), dan informasi terbaru dari sebuah produk fisik. Dimensi yang terakhir, VTS (Transaction), berhubungan dengan penggunaan teknologi internet untuk mengelola proses transaksi bisnis seperti pembayaran, pemesanan, dan pencetakan nota atau invoices.

\section{Penerapan dan Pengimplementasian Strategy E-business berdasarkan Model ICDT 3.1. Pengimplementasian strategy $e$-business berdasarkan dimensi VIS}

Menurut Angehrn (1997), tujuan dari dimensi VIS adalah untuk meningkatkan visibilitas dan persepsi terhadap organisasi baik untuk produk dan jasanya melalui teknologi internet. Bisa dikatakan bahwa dimensi VIS mengacu kepada penggunaan teknologi internet untuk mendukung kemampuan pemasaran atau marketing capability dari sebuah organisasi. Menurut Chang, dkk. (2010), marketing capability mengacu kepada kemampuan organisasi untuk tidak hanya menyediakan strategi marketing, tetapi juga kemampuan untuk mengimplementasikannya kedalam bentuk penetapan harga, periklanan dan memilih saluran marketing yang tepat. Oleh karena itu Chang, dkk. (2010) mengajukan Customer Relationship Management (CRM) sebagai salah satu strategi berbasis teknologi informasi yang dapat membantuk meningkatkan kemampuan pemasaran dari sebuah organisasi. Terkait dengan Trooper Electronic Yogyakarta, dimensi VIS diwujudkan dengan membangun sebuah web e-commerce yang menerapkan strategi CRM didalamnya. Menurut Tan, dkk. (2002), penerapan CRM di web e-commerce bisa diwujudkan dengan mengelola profil dari konsumen dan mengidentifikasi materi pemasaran yang tepat berdasarkan pengetahuan yang dikumpulkan dari aktifitas konsumen di web e-commerce. Dengan tersedianya teknologi CRM di sebuah web e-commerce, organisasi dapat menarik perhatian konsumen terhadap sebuah produk atau jasa, yang selanjutnya mengajak calon konsumen potensial untuk membeli produk dan jasa, dan dilanjutkan dengan mempertahankan relasi dengan konsumen tersebut (Wang, dkk., 2016).

Pada penelitian ini, pengimplementasian teknologi CRM pada web e-commerce untuk UMKM Trooper Electronic Yogyakarta dikembangkan menggunakan kerangka kerja CRM yang diusulkan oleh Gracia-Crespo, dkk. (2012). Gambar 3 menunjukkan model CRM untuk UMKM yang diajukan oleh Garcia-Crespo, dkk. (2012). Model CRM tersebut terbagi kedalam dua buah bagian yaitu operational CRM dan analytical CRM. Operational CRM mengacu kepada pengumpulan dan pengelolaan data terpusat yang berkaitan dengan transaksi bisnis yang didapatkan dari berbagai kegiatan operasional bisnis seperti transaksi di website atau komunikasi dengan konsumen melalui e-mail. Sementara itu, Analytical CRM mengacu kepada penggunaan data history yang didapatkan dari aktifitas yang menjadi bagian dari Operational CRM untuk dianalisis menggunakan metode tertentu untuk menghasilkan 
pengetahuan dalam bentuk laporan, analisis konsumen, analisis keuntungan dan analisis stok barang.

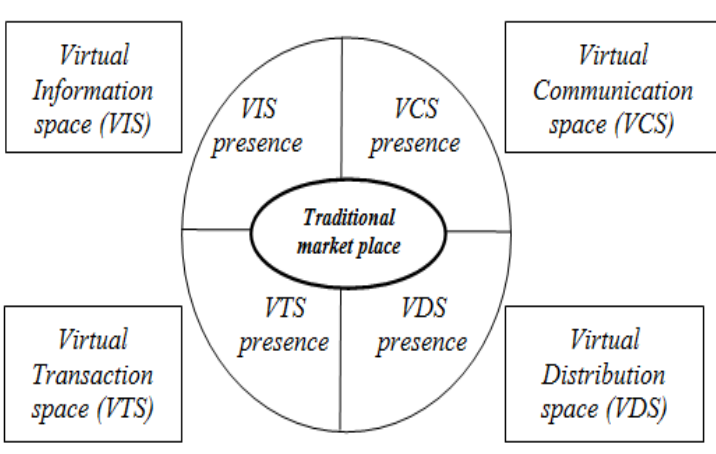

Gambar 2. Empat domain dari model ICDT (diadopsi dari Raisinghani, dkk. 2007)

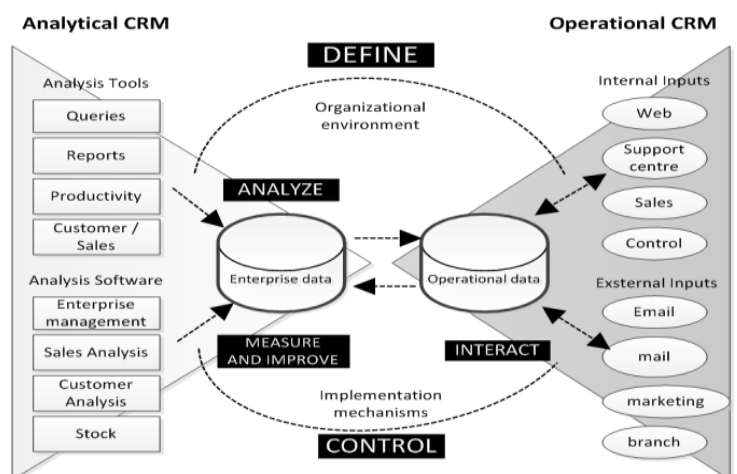

Gambar 3. Model CRM untuk Usaha Kecil Menengah (diadopsi dari Garcia-Crespo, dkk., 2012)

Berdasarkan kerangka kerja CRM di atas, pengimplementasian teknologi CRM pada web $e$ commerce Trooper Electronic Yogyakarta sebagai bentuk penerapan strategi e-business berdasarkan dimensi VIS diwujudkan dalam bentuk website yang memiliki fitur yang mencakup operational CRM dan Analytical CRM. Dalam konteks operational CRM, Web e-commerce yang dibangun memiliki fungsi diantaranya mengijinkan kosumen untuk melihat berbagai produk dari Trooper Electronic dan melakukan transaksi disana. Selanjutnya dalam konteks Analytical CRM, web e-commerce yang dibangun memiliki fitur sebagai berikut: (1) Laporan bagi pihak Trooper Electronic yang berisi rangkuman transaksi yang terjadi pada periode tertentu. (2) Fungsi rekomendasi kepada pihak Trooper Electronic apakah suatu produk lebih tepat jika dijual secara pre-order, siap rakit (pre-assembly), atau ready stock berdasarkan aktifitas dan kebiasan membeli konsumen di web $e$-commerce tersebut.

Perwujudan dari operational CRM berupa halaman web e-commerce yang menampilkan detil produk yang dijual oleh Trooper Electronic yang berisi informasi terkait barang tersebut seperti detil gambar, informasi teknis, serta video yang terkait dengan produk. Jika konsumen memutuskan untuk membeli produk tersebut, terdapat tombol "beli produk" yang apabila ditekan akan memasukkan barang tersebut kedalam daftar belanja (shopping cart) dari konsumen yang akan diakhiri dengan proses "check out" menuju ke pembayaran. Selanjutnya perwujudan dari analytical CRM ditunjukan dengan tersedianya laporan pendapatan dari penjualan barang berdasarkan produk yang terjual dalam kurun waktu tertentu. Pada laporan tersebut, Trooper Elektronik Yogyakarta bisa melihat total penjualan dari produk tertentu maupun total pejualan secara keseluruhan.

Implementasi dari analytical CRM selanjutnya ditunjukkan melalui halaman rekomendasi status ketersediaan stock dari produk Trooper Electronic yang dibagi kedalam tiga kategori yaitu "pre-order", "pre-assembly", atau "ready stock" berdasarkan kebutuhan dan proses bisnis yang saat ini sudah berjalan di Trooper Electronic. Status "pre-order" memiliki arti bahwa produk dari Trooper Electronic tidak langsung tersedia sehingga jika ada konsumen yang membelinya maka harus menunggu proses pembuatan produk tersebut dari awal. Sebagai contoh untuk produk efek gitar, Trooper Electronic harus merakit rangkaian elektroniknya terlebih dahulu, kemudia mencat casing dari efek dan kemudian merangkainya menjadi sebuah efek yang utuh. Untuk status "pre-assembly", pihak Trooper Electronic cukup menyiapkan casing nya saja karena rangkaian elektronik dari efek tersebut sudah tersedia dan menunggu untuk dirangkai menjadi sebuah produk jadi. Untuk status "ready stock" memiliki arti bahwa produk tersebut tersedia dan jika ada pesanan dari konsumen maka pihak Trooper Electronic bisa mengirimkan langsung ke konsumen. Gambar 4 menunjukkan halaman rekomendasi status stok dari produk Trooper Electronic.

Rekomendasi terhadap kategori stok barang diatas didasarkan pada aktifitas konsumen di web e-commerce yang terkait dengan produk tersebut. Setiap aktifitas dari konsumen yang menunjukkan ketertarikan terhadap produk yaitu melihat detil informasi dari produk, melihat 
detil foto dari produk, melihat video demo dari produk, memasukkan produk kedalam kantong belanja, dan pembelian terhadap produk tersebut akan dicatat dan disimpan untuk selanjutnya akan diolah hingga menghasilkan sebuah rekomendasi mengenai kategori dari stok barang.

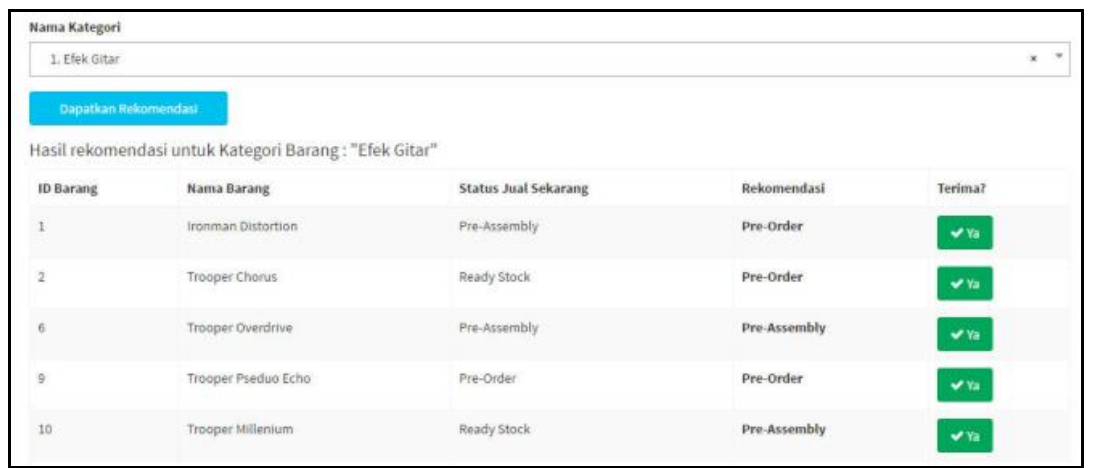

Gambar 4. Contoh Halaman Rekomendasi Stock Produk

Data aktifitas konsumen di web e-commerce di atas selanjutnya akan dianalisis menggunakan metode proses hirarki analitik yang strukturnya bisa dilihat pada Gambar 5 . Terdapat lima buah kriteria aktifitas yang menentukan ketertarikan konsumen terhadap sebuah produk. Kriteria dengan bobot teratas adalah aktifitas membeli barang dan diikuti aktifitas memasukkan produk kedalam troli belanja. Selanjutnya, untuk urutan kriteria yang tersisa yaitu aktifitas melihat detil informasi produk, melihat detil foto dari produk dan memutar video demo mengenai sebuah produk, ditentukan berdasarkan model komunikasi e-commerce yang diajukan oleh Xue, dkk. (2015). Dalam model yang diusulkan, Xue, dkk. (2015) menyatakan bahwa kognisi dan emosi mempengaruhi keputusan konsumen untuk melakukan pembelian. Berdasarkan argument tersebut, urutan dari ketiga kriteria tersisa akan diurutkan berdasarkan ciri khas dari aktivitas yang bisa menumbuhkan aspek kognisi dan emosi terbesar. Mengacu kepada produk dari UMKM Trooper Electronic yang sebagian besar berkaitan dengan alat musik (efek gitar dan amplifier), maka yang menjadi perhatian utama dari musisi selaku konsumen dari UMKM ini adalah suara dari produk tersebut dan diikuti dengan spesifikasi dan tampilan dari produk. Berdasarkan uraian diatas maka urutan teratas dari ketiga kriteria tersebut adalah aktifitas melihat video, sebab video menyampaikan informasi dalam bentuk visual dan audio sehingga mampu menyampaikan informasi dengan lengkap terutama untuk produk yang salah satu nilai jualnya adalah suara. Kriteria selanjutnya adalah detil produk (detil informasi yang cukup spesifik disajikan dalam bentuk teks) dan yang terakhir adalah detil gambar yang hanya menampilkan tampilan dari produk yang dalam hal produk efek gitar bukanlah faktor yang paling utama.

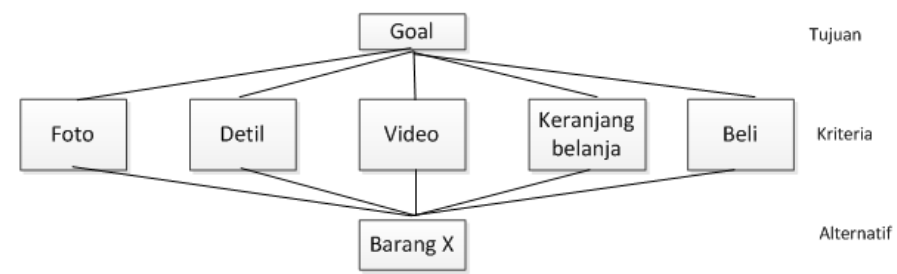

Gambar 5. Struktur Implementasi Proses Hirarki Analitik

Setelah strukur hirarki ditentukan, langkah selanjutnya adalah memberi nilai bobot masing-masing kategori stok produk. Pemberian nilai bobot diberikan oleh pihak Trooper Electronic selaku administrator dari web e-commerce seperti ditunjukan pada Gambar 6. Salah satu bentuk strategy e-business lainnya dari dimensi VIS yang bisa mendukung kemampuan marketing dari UMKM adalah pemanfaatan sosial media atau sering disebut dengan Social Commerce. Menurut Huang \& Benyoucef (2013), social commerce mengacu kepada 
pemanfaatan sosial media untuk mendukung proses bisnis melalui penyediaan konten dan interaksi didalamnya dengan tujuan untuk membantu konsumen dalam mengambil keputusan untuk membeli barang dan jasa. Dalam hal ini Trooper Electronic telah menerapkan strategi ini dengan membuat akun Facebook dan instagram yang juga terhubung dengan web e-commerce.

\begin{tabular}{|c|c|c|c|}
\hline Bobot | Status Jual Barang & Pre-Order & Pre-Assembly & Ready stock \\
\hline Bobot FOTO & $=$ & $\div$ & 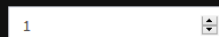 \\
\hline Bobot DETLLINFORMASI & $=$ & $\div$ & $\neq$ \\
\hline Bobot VIDEO PRODUK & $:$ & $\div$ & $1=$ \\
\hline Bobot CART/RROL & 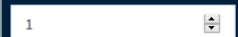 & $\because$ & 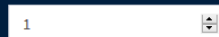 \\
\hline Bobot BELI & $\div$ & $\div$ & 1 \\
\hline Simpan & & & \\
\hline
\end{tabular}

Gambar 6. Antarmuka Pemberian Nilai Bobot Kriteria

\subsection{Pengimplementasian strategy $e$-business berdasarkan dimensi VCS}

Tujuan dari dimensi VCS (Virtual Communication Space) adalah untuk mendukung komunikasi antara para pelaku ekonomi melalui teknologi internet yang meliputi konsumen, calon konsumen, rekan kerja dan juga kompetitor. Dikarenakan ruang lingkup usaha dari Trooper Eletronic yang masih terbatas, maka penerapan strategi e-business dari dimensi VCS lebih difokuskan kepada relasi dengan konsumen (B2C). Terkait dengan VCS, E-commerce Communication Model (ECM) yang diusulkan oleh Xue dkk. (2015) bisa diterapkan untuk mengoptimalkan strategi e-business pada web e-commerce yang dibangun pada penelitian ini.

Model ECM (Gambar 7) menjabarkan pola komunikasi didalam e-commerce kedalam tiga tahapan. Tahapan yang pertama mengacu kepada bagaimana konsumen bisa mendapatkan informasi mengenai produk atau jasa dari sebuah unit usaha. Tahap pertama ini menjadi sangat krusial karena disinilah alur komunikasi akan terbentuk. Tahapan pertama ini terbagi menjadi dua buah bagian yaitu konsumen mendapatkan informasi mengenai produk atau jasa dari hasil mesin pencarian atau langsung dari website, dan yang kedua, konsumen memperoleh informasi dari iklan (Xue, dkk., 2015). Pada tahapan ini banyak strategi yang bisa diterapkan untuk menarik perhatian dari konsumen seperti penggunaan search engine optimization dan berbagai strategi marketing lainnya yang membutuhkan sumber daya yang tidak sedikit. Terkait dengan hal itu, terdapat beberapa strategi yang cukup murah dan mudah untuk meraih perhatian dari calon konsumen, yang terkait dengan penggunaan media sosial.

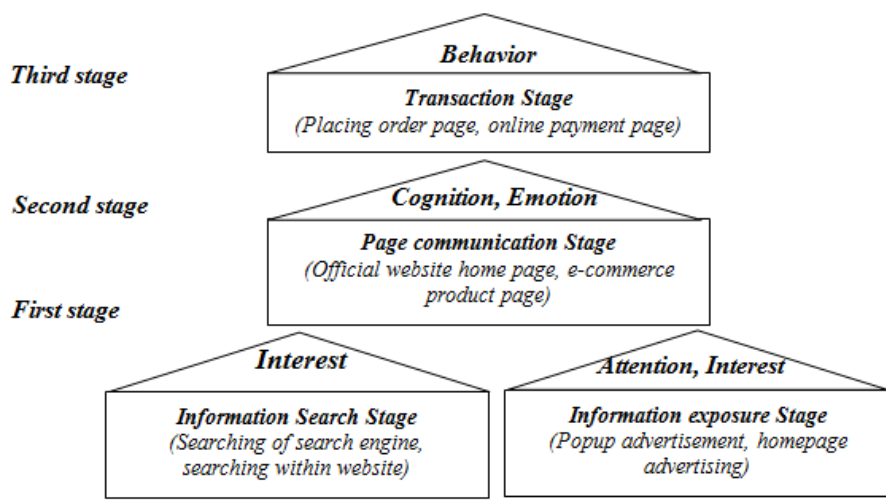

Gambar 7. E-commerce Communication Model (diadopsi dari Xue, dkk. 2015).

Menurut Öztamur \& Karakadılar (2014), terdapat beberapa pelaku usaha yang menggunakan hashtag dengan kata kunci tertentu disetiap konten yang mereka publikasikan dengan tujuan untuk menarik calon pelanggan potensial. Strategi tersebut juga diterapkan oleh Trooper Electronic dengan memberikan hashtag dengan kata kunci yang berkaitan dengan alat 
musik untuk setiap konten gambar maupun video demo dari produk mereka yang diposting di Instagram (Gambar 8). Dengan menyertakan hashtag pada setiap konten yang dipublikasikan, calon konsumen potensial yang tertarik akan sebuah produk berdasarkan kata kunci tertentu dapat berpeluang memperoleh informasi mengenai produk dari Trooper Electronic.

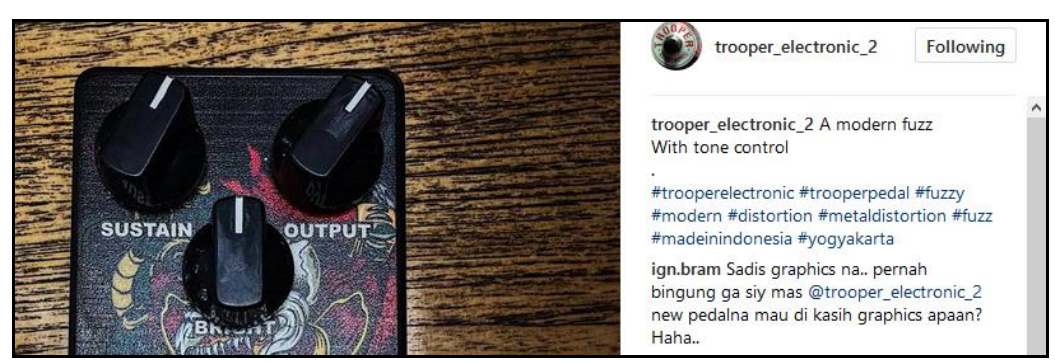

Gambar 8. Contoh Penggunaan Hashtag Pada Konten di Instagram.

Selanjutnya tahap kedua dari Model ECM adalah page communication stage. Tahapan ini merupakan tahapan yang paling krusial dari model komunikasi ini dikarenakan keputusan untuk membeli atau tidak ditentukan pada tahapan ini (Xue, dkk., 2015). Pada tahapan ini konsumen akan memperoleh semua informasi yang dibutuhkan untuk mengambil keputusan di tahapan komunikasi selanjutnya yaitu transaction stage. Oleh karena itu semua informasi yang ditampilkan harus mampu menghilangkan keraguan konsumen terhadap sebuah produk.

Terkait dengan hal tersebut, pada pengimplementasian web e-commerce untuk Trooper Electronic, data dan informasi mengenai produk ditampilkan menggunakan tiga media yaitu dalam bentuk teks untuk menampilkan spesifikasi dari produk, dalam gambar untuk menyampaikan tampilan produk secara visual, dan dalam bentuk video audio dikarenakan produk yang dijual oleh Trooper Electronic berupa produk alat musik dan selain itu konsumen juga perlu mendapatkan informasi mengenai kinerja dari produk tersebut dalam bentuk audio.

Tahapan yang terakhir dari model ECM adalah transaction stage. Pada tahapan ini konsumen akan melakukan pemesanan dan melakukan pembayaran. Pada tahapan ini strategi yang diajukan oleh Xue, dkk. (2015) adalah dengan menyediakan mekanisme pembayaran dan pengiriman produk yang jelas dan terdapat kepastian mengenai layanan purnajual. Penerapan strategi pada tahapan ketiga ini akan dibahas pada penerapan strategi dari dimensi VTS (Virtual Transaction Space) yang juga mencakup strategi yang berhubungan dengan pengelolaan transaksi pembayaran.

\subsection{Pengimplementasian strategy $e$-business berdasarkan dimensi VDS}

Tujuan dari dimensi VDS (Virtual Distribution Space) adalah mendistribusikan produk dan jasa melalui internet seefektif dan seefisien mungkin. Seperti telah dijelaskan di landasan teori bahwa produk dan jasa pada dimensi ini dikategorikan menjadi tiga jenis yaitu produk digital, layanan digital dan layanan tambahan yang terkait dengan layanan tradisional. Terdapat berbagai macam bentuk strategi yang bisa diajukan pada dimensi ini salah satunya adalah dengan menawarkan produk yang relevan dengan konsumen. Qiu, dkk. (2015) mengajukan model untuk memprediksi prilaku pembelian konsumen berdasarkan asosiasi antar produk yang diminati oleh konsumen dan berdasarkan faktor-faktor eksternal seperti trend, kebutuhan ekonomi, kesukaan terhadap merk tertentu, harga dan lainnya.

Pada pembangungan web e-commerce ini, strategi di atas diterapkan dalam bentuk penawaran produk alternatif yang berasosiasi dengan produk yang sedang dilihat oleh konsumen. Pada setiap detil produk yang sedang dilihat oleh konsumen, sistem secara otomatis akan menampilkan produk produk lainnya yang berasosiasi dengan produk tersebut. Asosiasi antar produk tersebut diperoleh dari hasil query terhadap data kombinasi sebuah produk dengan produk lainnya yang terdapat pada data transaksi yang dilakukan oleh konsumen lain sebelumnya. Gambar 9 menunjukan penawaran beberapa produk lain yang berhubungan dengan produk yang sedang dilihat oleh konsumen. 


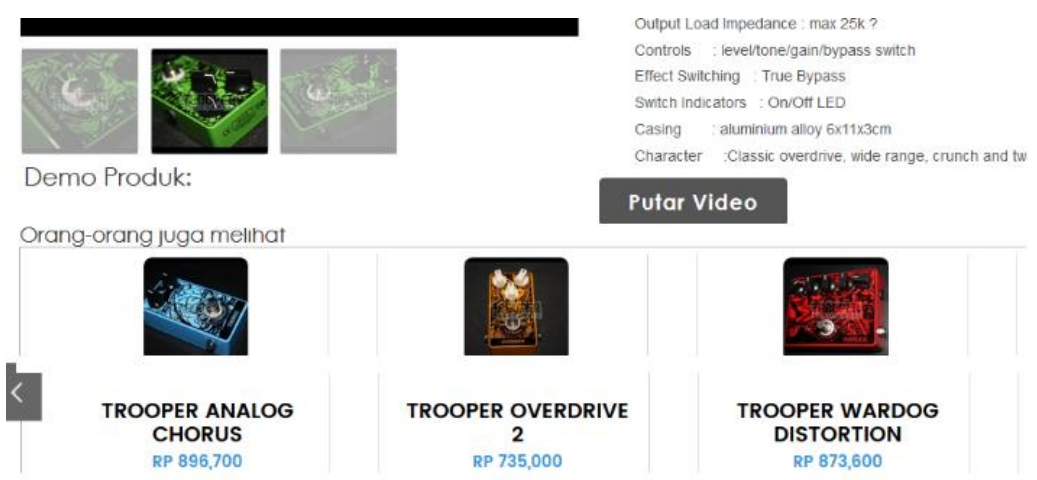

Gambar 9. Contoh Tampilan Referensi Produk

\subsection{Pengimplementasian strategy e-business berdasarkan dimensi VTS}

Dimensi yang terakhir, VTS (Virtual Transaction Space) mengacu kepada pemanfaatan teknologi internet untuk menangani transaksi bisnis seperti pemesanan, pembayaran, pencetakan nota dan layanan purnajual. Terkait dengan dimensi ini, model e-payment ontology dari Trappey dkk. (2016) dapat digunakan untuk menyusun strategi e-business yang sesuai. Seperti ditunjukan pada Gambar 10, e-payment ontology terdiri dari tiga elemen yaitu payment channel yang berhubungan dengan bagaimana konsumen akan melakukan pembayaran, payment security yang berhubungan dengan keamanan data dan pencegahan penipuan, dan payment management yang berhubungan dengan aktifitas sebelum dan sesudah tansaksi seperti penyediaan solusi jika terjadi kesalahan dalam transaksi dan layanan purnajual lainnya.

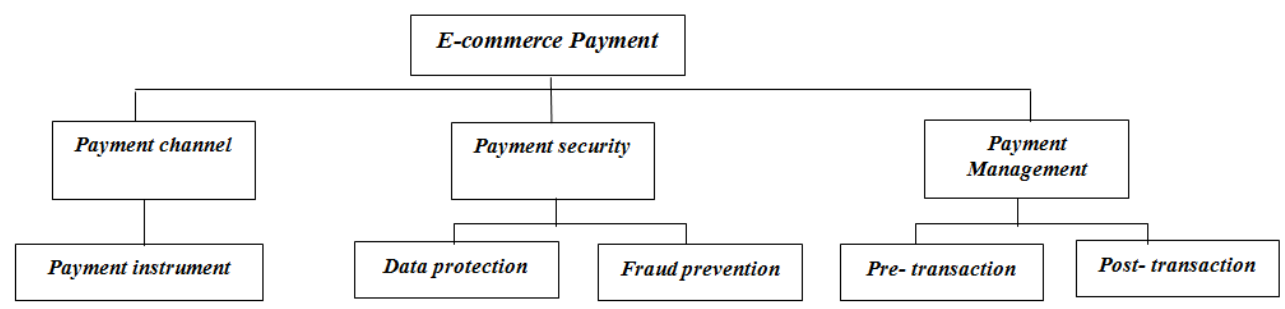

Gambar 10. E-payment Ontology (diadopsi dari Trappey, dkk., 2016)

Terkait dengan element pertama dari e-payment ontology di atas, web e-commerce yang dikembangkan untuk UMKM Trooper Electronic mencoba untuk mengimplementasikan strategi tersebut dengan menyesuaikan dengan kondisi dari Trooper Electronic sendiri. Mengingat saat ini Trooper Electronic belum memiliki kemampuan untuk membangun kerja sama dengan bank dalam hal pembayaran otomatis, maka semua proses pembayaran masih harus dilakukan secara manual melalui transfer ke rekening yang dimiliki oleh Trooper Electronic. Untuk mempermudah proses tersebut, maka web e-commerce yang dibangun, menyediakan mekanisme yang membantu konsumen untuk melakukan konfirmasi pembayaran dengan mengupload bukti pembayaran berdasarkan kode pemesanan. Nantinya konsumen bisa memeriksa status pesanannya pada halaman history transaksi. Pada halaman tersebut konsumen bisa memperoleh informasi mengenai status transaksi apakah sedang dalam proses ataupun telah dikirim.

Selanjutnya terkait dengan element payment ontology yang kedua, yaitu payment security, pihak Trooper Electronic harus menjamin bahwa semua data transaksi yang diterima tidak disebarkan kepada pihak ketiga yang tidak berkepentingan. Selain itu untuk memastikan keamanan datanya, web e-commerce harus dihosting ke penyedia jasa web hosting yang dapat dipercaya. Untuk elemen yang ketiga yaitu payment management, pihak Trooper Electronic harus bisa menyediakan data yang terkait dengan transaksi tertentu apabila ditemukan kemudian hari terdapat permasalahan terhadap transaksi tersebut. Untuk itulah semua bukti transaksi yang meliputi nota pemesanan sampai dengan bukti pembayaran harus disimpan dan masih bisa 
diakses oleh pihak Trooper Electronic selaku administrator dari web e-commerce.

\section{Pengujian Web E-commerce}

Terdapat dua macam pengujian dari web e-commerce yang diberikan kepada responden, yaitu pengujian antarmuka dan fasilitas panel admin dan pengujian antarmuka dan fasilitas e-commerce Trooper Electronic.

\subsection{Pengujian Antarmuka dan Fasilitas Panel Admin}

Responden yang diambil dalam pengujian ini adalah pemilik UMKM Trooper Electronic. Pengujian ini dilakukan untuk menguji apakah antarmuka panel admin nyaman digunakan dan fungsionalitasnya dapat berjalan sesuai dengan kebutuhan. Detil pengujian pada tahapan ini dapat dilihat pada Tabel 1. Rekapitulasi data yang diperoleh dari setiap pernyataan pengujian di Tabel 1 adalah sebagai berikut: (a) Pernyataan satu: Responden menjawab setuju (b) Pernyataan dua: Responden menjawab sangat setuju (c) Pernyataan tiga: Responden menjawab setuju (a) Pernyataan empat: Responden menjawab setuju. (e) Pernyataan lima: Responden menjawab sangat setuju. Berdasarkan rekapitulasi data yang diperoleh maka dapat diambil suatu kesimpulan bahwa aplikasi web e-commerce dari sisi panel admin telah berjalan sesuai dengan kebutuhan dan nyaman digunakan.

Tabel 1. Tabel Pengujian Antarmuka dan Fasilitas Panel Admin

\begin{tabular}{|c|c|c|c|c|c|}
\hline \multirow[t]{2}{*}{ NO } & \multirow[t]{2}{*}{ PERTANYAAN } & \multicolumn{4}{|c|}{ PILIHAN JAWABAN } \\
\hline & & SS & $\mathbf{S}$ & $\mathbf{K S}$ & TS \\
\hline 1 & Pengujian Antarmuka dan Fasilitas E-commerce Trooper Electronic & 0 & 1 & 0 & 0 \\
\hline 2 & $\begin{array}{l}\text { Secara umum saya menyukai tampilan antarmuka panel admin Panel admin membantu saya } \\
\text { dalam mengelola transaksi }\end{array}$ & 1 & 0 & 0 & 0 \\
\hline 3 & $\begin{array}{l}\text { Pengelolaan data transaksi misalnya pengelolaan barang, pemesanan, atau pembayaran mudah } \\
\text { saya pahami }\end{array}$ & 0 & 1 & 0 & 0 \\
\hline 4 & Secara umum saya merasa nyaman menggunakan panel admin ini & 0 & 1 & 0 & 0 \\
\hline
\end{tabular}

\subsection{Pengujian Antarmuka dan Fasilitas E-commerce Trooper Electronic}

Responden yang diambil dalam pengujian ini adalah 32 responden dengan rata-rata usia 19 sampai dengan 49 tahun dengan latar belakang pekerjaan yang beragam. Di dalam pengujian ini, responden bertindak sebagai pelanggan dari Trooper Electronic dan diminta untuk menguji aplikasi e-commerce. Pengujian ini dilakukan untuk menguji dan untuk mengukur bahwa antarmuka dan interaksi aplikasi e-commerce membantu pengguna dalam mencari informasi produk dan membantu memberikan kemudahan serta kenyamanan dalam bertransaksi. Detil pengujian pada tahapan ini dapat dilihat pada Tabel 2. Rekapitulasi data yang diperoleh dari setiap pernyataan pengujian di Tabel 2 adalah sebagai berikut: (a) Pernyataan satu: Sebanyak $22 \%$ responden manyatakan sangat setuju, $75 \%$ responden menyatakan setuju, dan 3\% responden menyatakan kurang setuju. (b) Pernyataan dua: Sebanyak 34\% responden manyatakan sangat setuju dan $66 \%$ responden menyatakan setuju. (c) Pernyataan tiga: Sebanyak 47\% responden menyatakan sangat setuju, $47 \%$ reponden lainnya menyatakan setuju, dan $6 \%$ responden sisanya menjawab kurang setuju. (d) Pernyataan empat: Sebanyak 59\% responden manyatakan sangat setuju dan $41 \%$ responden menyatakan setuju. (e) Pernyataan lima: Sebanyak 56\% responden manyatakan sangat setuju dan $44 \%$ responden menyatakan setuju. (f) Pernyataan enam: Sebanyak 19\% responden manyatakan sangat setuju dan $81 \%$ responden menyatakan setuju. (g) Pernyataan tujuh: Sebanyak 38\% responden manyatakan sangat setuju, 59\% responden menyatakan setuju, dan 3\% menyatakan kurang setuju. Berdasarkan rekapitulasi data yang diperoleh maka dapat diambil suatu kesimpulan bahwa sebagian besar responden merasa nyaman dalam bertransaksi di e-commerce Trooper Electronic. Selain itu, sebagian besar responden merasa terbantu untuk mendapatkan informasi dan pengenalan produk dari UMKM Trooper Electronic dan fasilitas email, referensi produk, dan histori transaksi pemesanan yang e-commerce sediakan. 
Tabel 2. Tabel Pengujian Antarmuka dan Fasilitas E-commerce

\begin{tabular}{|c|c|c|c|c|c|}
\hline \multirow[t]{2}{*}{ NO } & \multirow[t]{2}{*}{ PERTANYAAN } & \multicolumn{4}{|c|}{ PILIHAN JAWABAN } \\
\hline & & SS & $\mathbf{S}$ & KS & TS \\
\hline 1 & Secara umum saya menyukai tampilan antarmuka $e$-commerce & 7 & 24 & 1 & 0 \\
\hline 2 & $\begin{array}{l}\text { Adanya e-commerce membantu saya memperoleh informasi mengenai produk-produk dari } \\
\text { Trooper Electronic }\end{array}$ & 11 & 21 & 0 & 0 \\
\hline 3 & $\begin{array}{l}\text { Adanya email pemberitahuan saat pendaftaran untuk verifikasi email, saya merasa dipermudah } \\
\text { berbelanja di } e \text {-commerce }\end{array}$ & 15 & 15 & 2 & 0 \\
\hline 4 & Bagian "Histori Transaksi" di halaman Profil membantu saya untuk mengetahui transaksi saya & 19 & 13 & 0 & 0 \\
\hline 6 & Proses transaksi di e-commerce Trooper Electronic mudah dipahami dan dilakukan & 6 & 26 & 0 & 0 \\
\hline 7 & Secara umum saya merasa nyaman berbelanja di e-commerce Trooper Electronic ini & 12 & 19 & 1 & 0 \\
\hline
\end{tabular}

\section{Kesimpulan}

Penerapan strategi e-business tidak dapat diimplementasikan begitu saja tanpa memperhatikan strategi bisnis dan kondisi dari sebuah unit usaha, terutama untuk UMKM. Oleh sebab itu para pelaku UMKM perlu untuk memastikan bahwa strategi e-business yang mereka pilih tepat dan bisa meningkatkan keunggulan kompetitif mereka. Dengan tersedianya sebuah model atau kerangka kerja yang mampu mengevaluasi dan menuntun penyusunan strategi $e$ business, peluang UMKM untuk meningkatkan dan mengembangkan proses bisnis dari usaha mereka menjadi lebih besar.

Berhubungan dengan hal tersebut UMKM Trooper Electronic Yogyakarta menggunakan model strategi e-business yang diusulkan oleh Raisinghani, dkk. (2007) yang diadopsi dari model ICDT untuk menerapkan strategi e-business dalam bentuk pembangunan web e-commerce dan pemanfaatan sosial media untuk meningkatkan keunggulan kompetitif dari UMKM tersebut. Hasil dari penelitian ini adalah berhasil dibangunnya sebuah web e-commerce yang memiliki fitur yang dikembangkan berdasarkan model ICDT yang didukung dengan pemanfaatan sosial media untuk membantu UMKM Trooper Electronic dalam mengembangkan usahanya dan diharapkan dapat meningkatkan keunggulan kompetitif mereka.

Untuk kedepannya, penerapan strategy e-busines bisa diwujudkan dalam bentuk pengintegrasian teknologi web e-commerce dengan sosial media mengingat saat ini sosial media juga telah berkembang menjadi sebuah saluran yang juga dipergunakan untuk menjalankan transaksi oleh banyak pelaku usaha, yang dikenal dengan istilah social commerce.

\section{Referensi}

Angehrn, A. A. (1997). The ICDT model: towards a taxonomy of internet-related business strategies. INSEAD.

Chang, W., Park, J. E., \& Chaiy, S. (2010). How does CRM technology transform into organizational performance? A mediating role of marketing capability. Journal of Business Research, 63(8), 849-855.

Garcia-Crespo, Á., Colomo-Palacios, R., Gómez-Berbís, J. M., \& Martín, F. P. (2012). Customer relationship management in social and semantic web environments. Successful Customer Relationship Management Programs and Technologies: Issues and Trends: Issues and Trends, 83.

Hasan, H., \& Tibbits, H. (2000). Strategic management of electronic commerce: an adaptation of the balanced scorecard. Internet Research, 10(5), 439-450.

Huang, Z., \& Benyoucef, M. (2013). From e-commerce to social commerce: A close look at design features. Electronic Commerce Research and Applications, 12(4), 246-259.

Kaplan, R. S., \& Norton, D. P. (2005). The balanced scorecard: measures that drive performance. Harvard Business School Publishing, January-February, 71-79.

Lu, Q., \& Liu, N. (2015). Effects of e-commerce channel entry in a two-echelon supply chain: A comparative analysis of single-and dual-channel distribution systems. International Journal of Production Economics, 165, 100-111.

Martinsons, M., Davison, R., \& Tse, D. (1999). The balanced scorecard: a foundation for the strategic management of information systems. Decision support systems, 25(1), 71-88. 
Öztamur, D., \& Karakadılar, İ. S. (2014). Exploring the role of social media for SMEs: as a new marketing strategy tool for the firm performance perspective. Procedia-Social and behavioral sciences, 150, 511-520.

Plant, R., Willcocks, L., \& Olson, N. (2003). Measuring e-business performance: towards a revised balanced scorecard approach. Information Systems and e-business Management, 1(3), 265-281.

Poorangi, M. M., Khin, E. W., Nikoonejad, S., \& Kardevani, A. (2013). E-commerce adoption in Malaysian Small and Medium Enterprises Practitioner Firms: A revisit on Rogers' model. Anais da Academia Brasileira de Ciências, 85(4), 1593-1604.

Pramudiya, H. E., Handarkho, Y. D., \& Rahayu, F. S. (2015). Pengimplementasian CRM Pada Pembangunan E-Commerce untuk Usaha Mikro Kecil Menengah (Studi Kasus: Dolanan Puzzle). Jurnal Buana Informatika, 6(4), pp. 257-268.

Qiu, J., Lin, Z., \& Li, Y. (2015). Predicting customer purchase behavior in the e-commerce context. Electronic commerce research, 15(4), 427-452.

Rahayu, R., \& Day, J. (2015). Determinant factors of e-commerce adoption by SMEs in developing country: evidence from Indonesia. Procedia-Social and Behavioral Sciences, 195, 142-150.

Raisinghani, M. S. (2001). A Balanced Analysis Approach to Strategic Electronic Commerce Decisions: A Framework of the Evaluation Method. In Information technology evaluation methods and management (pp. 185-197). IGI Global.

Raisinghani, M. S., Meade, L., \& Schkade, L. L. (2007). Strategic e-business decision analysis using the analytic network process. IEEE transactions on Engineering Management, 54(4), 673-686.

Sudirman, I., Govindaraju, R., Samadhi, T. A., \& Saptadi, S. (2015). Business strategy and ebusiness initiatives in Indonesian B-to-B manufacturing SMEs. In Electric Vehicular Technology and Industrial, Mechanical, Electrical and Chemical Engineering (ICEVT \& IMECE), 2015 Joint International Conference (pp. 396-400). IEEE.

Stale, G., \& Majors, I. (2010, April). Applying knowledge Management methods and enterprise modelling solution to the IT "ecosystem" for continuing education in SME's. In Digital Ecosystems and Technologies (DEST), 2010 4th IEEE International Conference on (pp. 464-469). IEEE.

Tan, X., Yen, D. C., \& Fang, X. (2002). Internet integrated customer relationship management a key success factor for companies in the e-commerce arena. Journal of Computer Information Systems, 42(3), 77-86.

Trappey, A. J., Trappey, C. V., \& Hsu, A. (2016). Modeling Technology Roadmaps Of ECommerce Payment Systems Based On Patent Informatics. International Journal of Electronic Business Management, 14, pp. 24-34

Van Grembergen, W., \& Amelinckx, I. (2002, January). Measuring and managing e-business projects through the balanced scorecard. In System Sciences, 2002. HICSS. Proceedings of the 35th Annual Hawaii International Conference on (pp. 9-pp). IEEE.

Wang, S., Cavusoglu, H., \& Deng, Z. (2016). Early mover advantage in e-commerce platforms with low entry barriers: The role of customer relationship management capabilities. Information \& Management, 53(2), 197-206.

Xue, J., Niu, Y., \& Yu, W. (2015, July). Research on E-commerce Communication Model and driven strategies. In Logistics, Informatics and Service Sciences (LISS), 2015 International Conference on (pp. 1-5). IEEE.

Yee-Loong Chong, A., Ooi, K. B., Bao, H., \& Lin, B. (2014). Can e-business adoption be influenced by knowledge management? An empirical analysis of Malaysian SMEs. Journal of Knowledge Management, 18(1), 121-136. 